\title{
A strategic thinking of the scientific system of drug regulatory in China - advancing drug standards of China
}

\author{
Fucheng Zhou
}

\begin{abstract}
From 2012 Sino-American Symposium on Clinical and Translational Medicine (SAS-CTM) Shanghai, China. 27-29 June 2012
\end{abstract}

Drug is special goods to prevent diseases or used for rehabilitation and health care, and therefore is essential for human society development. Drug safety directly related to people's health and life safety, and also tightly associated with the government management and public safety. Our national pharmaceutical and health care policy has paid equal attentions on Traditional Chinese Medicine and western chemical drugs, and implemented the significant new drugs creation strategy. Plenty of strategies, approaches and technologies have been applied in the drug research field, and have promoted the fast development of biomedical industry. Now we are on the way to be a big country of pharmacy, which supplies favorable conditions and available development spaces of constructing the novel drug regulatory system.

According to the overall serious problems of China biomedical industry, such as small scale, low concentration; excess capacity, weak innovation and competition on market, and homogenization under low-end technology and quality, etc. Additionally, the development of society is facing urbanization, industrialization and aging problems, new requirements of the safety, efficient and availableness of drug have been raised. Therefore, Constructing the new system of national drug regulatory, improve the level of drug quality control and ensure the drug safety in society are essential products as the progress of times and society development, and also are important questions that to pay more attentions during drug regulatory process. We need to deeply understand them with the basis of practice and innovate drug concept and measures, to ensure the drug safety and efficient is controllable. After all, we need to persist on thinking systematically, enhance the top design,

Correspondence: zfc_china@163.com

Pharmacopeia Commission of China, Beijing, China emphasize on the entire process regulatory, to construct a new system of drug regulatory which is suitable to domestic conditions.

Published: 17 October 2012

doi:10.1186/1479-5876-10-S2-A39

Cite this article as: Zhou: A strategic thinking of the scientific system of drug regulatory in China - advancing drug standards of China. Journal of Translational Medicine 2012 10(Suppl 2):A39.

Submit your next manuscript to BioMed Central and take full advantage of:

- Convenient online submission

- Thorough peer review

- No space constraints or color figure charges

- Immediate publication on acceptance

- Inclusion in PubMed, CAS, Scopus and Google Scholar

- Research which is freely available for redistribution 